\title{
Contribution of IgG avidity and PCR for the early diagnosis of toxoplasmosis in pregnant women from the North-Eastern region of Algeria.
}

\author{
Hajira Berredjem ${ }^{1,2}$, Hayette Aouras ${ }^{3}$, Meriem Benlaifa $^{2}$, Imène Becheker ${ }^{1}$, Mohamed Reda Djebar ${ }^{2}$
}

1. Department of Biochemistry, Faculty of Sciences, University of Badji Mokhtar, Annaba, Algeria

2. Laboratory of Cellular Toxicology, Faculty of Sciences, University of Badji Mokhtar, Annaba, Algeria

3. Service of Gynecology, EHS Abdallah Nouaouria Hospital, El Bouni-Annaba, Algeria

\begin{abstract}
:
Background: Acute toxoplasmosis in pregnant women presents a high risk of Toxoplasma transmission to the fetus. Early diagnosis is difficult, especially when serological testing for $\operatorname{IgG} / \operatorname{IgM}$ antibodies fail to differentiate between a recent and a past infection. In this case, we rely on IgG avidity or PCR assays.

Objectives: The aim of this study was to compare conventional ELISA and IgG avidity, with PCR using B1 and P30 primers for the early diagnosis of toxoplasmosis in pregnant women.

Methods: Sera were collected from 143 pregnant women and measured by ELISA for anti-Toxoplasma IgG, IgM, IgA and IgG avidity. DNA was extracted from 57 peripheral blood and 14 amniotic fluid samples for PCR amplification.

Results: A total of 57 out 143 women were seropositive: 30 (52.6\%) were IgG+/IgM- and 27 (43.8\%) were $\operatorname{IgG}+/ \operatorname{IgM}+$; IgA antibodies were positive in $7(12.2 \%)$ cases. IgG avidity was low in 9 women suggesting an acute infection; 3 women presented an intermediate avidity. PCR detected Toxoplasma DNA in 9 women presenting low avidity and was negative for the intermediate avidity cases.

Conclusion: PCR combined to avidity IgG performed better than ELISA IgG, IgM and/or IgA assays alone. PCR was useful in the case of intermediate avidity.

Keywords: Toxoplasmosis, pregnant women, serology, IgG avidity, PCR.

DOI: https://dx.doi.org/10.4314/ahs.v17i3.7

Cite as: Berredjem H, Aouras H, Benlaifa M, Becheker I, Djebar MR. Contribution of IgG avidity and PCR for the early diagnosis of toxoplasmosis in pregnant women from the North-Eastern region of Algeria. Afri Health Sci. 2017;17(3): 647-656. bttps://dx.doi.org/10.4314/ abs.v17i3.7
\end{abstract}

\section{Introduction:}

Toxoplasmosis, caused by the intracellular parasite Toxoplasma gondii ( $T$ gondii), is one of the most prevalent diseases in humans ${ }^{1}$. This disease is generally asymptomatic in immunocompetent human host ${ }^{2}$. However, $T$ gondii causes substantial morbidity and mortality in immunocompromised patients ${ }^{3,4}$ and in congenitally infected infants ${ }^{5}$. Infection acquired by pregnant women immediate-
Corresponding author:
Hajira Berredjem,
Department of Biochemistry,
Faculty of Sciences,
University of Badji Mokhtar
PO Box 12 Sidi Amar 23000, Annaba (Algeria)
Tel: (00213) 38-87-10-61
hajira.berredjem@univ-annaba.dz
and h_berjem@yahoo.fr

ly before or during gestation and its transmission to the fetus continues to be the cause of tragic yet preventable diseases, which may be more or less severe depending on the date of transmission ${ }^{6}$. Congenital infection acquired during the early stages of pregnancy often results in severe fetal signs such as severe neurological damages, or fetal death. Infection acquired later, within the second or third trimester, is more likely to be asymptomatic at birth leading usually to much less severe injury of the newborn and later of the child ${ }^{7}$. A rapid and accurate diagnosis is required in order to start the relatively efficient anti-parasitic treatment ${ }^{8}$.

Current diagnosis of toxoplasmosis relies mainly on serological detection of specific IgG and IgM, on fibroblast cell culture or mice inoculation of amniotic fluid or fetal blood $^{3,9}$. The presence of IgM is, in general, an indication that the host has recently been infected. However, these antibodies can persist for months or even years after acute infection. Consequently, the concomitant presence 
of $\operatorname{IgM}$ and $\operatorname{IgG}$ does not always indicate an acute infection, so it is necessary to study antibody kinetics based on a serological control 2-3 weeks later ${ }^{10}$. Moreover, serological testing may fail during the active phase of T. gondii infection because the antibodies titres are low; therefore, the high risk of congenital toxoplasmosis of a fetus may be undetected because the pregnant mother might test negative during the active phase of $T$. gondii infection. When high levels of $\mathrm{IgG}$ antibodies are present in sera, serological testing does not distinguish a recent infection from one acquired a longtime before and detection of specific IgM response cannot help determine if infection was recent ${ }^{11}$. This inconvenience has limited the use of the serological tests. More studies have shown that $\operatorname{IgG}$ avidity assay ${ }^{10,14,15}$ or polymerase chain reaction $(\mathrm{PCR})^{12,13}$ are useful for identification or exclusion of $T$. gondii acute infection, or for estimation at the time of seroconversion.

In this study, $\operatorname{Ig} G$ avidity and PCR have been evaluated, on the basis of the results obtained with conventional serological tests, as a diagnostic tool for the diagnosis of toxoplasmosis in Algerian pregnant women, and for the descrimination between acute and chronic infection.

\section{Patients and methods:}

This prospective study was carried out at Abdallah Nouaouria Hospital, El Bouni-Annaba. Peripheral blood (PBL) and amniotic fluid (AF) samples were collected during diagnosis for toxoplasmosis in 143 pregnant women, between 22 and 43 years old. None of the mothers had apparent symptoms of toxoplasmosis during their pregnancy and no antibiotic drugs were previously prescribed to the patients. Two blood samples, with respectively an interval of 21 days, were taken from each patient. Therefore, a total of 286 sera samples were checked for anti-Toxoplasma antibodies by serological tests : IgG, IgM and IgA ELISA assay. A total of 57 samples (one sample from each patient) with a positive anti-Toxoplasma $\mathrm{IgG}$ were further analysed using the $\mathrm{IgG}$ avidity. Blood and AF samples were taken for DNA extraction. Gene amplification was processed on 57 PBL samples; PCR on AF was done to 14 women suspected to have acute infection which can lead to a congenital toxoplasmosis. This study was approved by the Hospital Ethical Committee, and informed consent was obtained from all the patients.

\section{IgG, IgM and IgA ELISA}

All patients' sera were tested for the presence of specific $\operatorname{IgG}, \operatorname{IgM}$ and $\operatorname{IgA}$ antibodies to Toxoplasma using an ELISA kits (Platélia Toxo, Diagnostic Pasteur, France) according to the manufacturer's instructions. The anti-Toxoplasma IgG, expressed in IU, were calculated from a standard curve. «Double sandwich » ELISA was used for the detection of IgM and IgA antibodies. Sera samples were processed in duplicate.

\section{IgG avidity}

The Toxoplasma-specific IgG avidity assay was performed by ELISA (SFRI ${ }^{\circledR}$ laboratoire, France) to discriminate between acute and chronic infection. A total of 57 sera samples were diluted $1 / 200$ and added (100 $\mu \mathrm{l} /$ well $)$ on 2 rows of a plate (row $\mathrm{A}$ and row B). After $45 \mathrm{~min}$ of incubation at $37^{\circ} \mathrm{C}$, the row $\mathrm{B}$ was washed 3 times with the modified PBST buffer containing $6 \mathrm{M}$ urea and 4 times with PBST containing 0.05\% Tween 20 in order to remove low-avidity antibodies from their binding sites. The control row A was washed 3 times with buffer without urea. The anti-human IgG conjugated with horseradish peroxidase (Dako Glostrup, Denmark) was added with the dilution of $1 / 1000$ in PBST. After incubation and washing, the chromogenic substrate, O-phenylenediamine (Merk, Darmstadt, Germany), was added. The reaction was stopped by addition of sulfuric acid $20 \%$. The absorbance was read at $492 \mathrm{~nm}$. The $\mathrm{IgG}$ avidity index (AI: \%) was calculated on the basis of the formula : $\mathrm{AI}=$ Abs $($ PBS-urea $) /$ Abs $($ PBST $) \times 100$.

Three different avidity classes were determined: AIs lower than $25 \%$, between $25 \%$ and $35 \%$, and above $35 \%$ were classified as low, intermediate, and high avidity, respectively.

\section{DNA parasite preparation}

DNA extracted from the tachyzoites of T. gondii-RH strain (Institut Pasteur, Tunis) was used as positive control for PCR. The parasites were harvested from the peritoneal exudate of Swiss-Webster female mouse intraperitoneally infected 3 days earlier. The DNA parasite was extracted using the salting out method. The concentration of purified DNA was mesured by UV spectrophotometry (GENEQUANT, pharmacia Biotech). The DNA samples were stored at $-20^{\circ} \mathrm{C}$. 
Polymerase chain reaction of T. gondii B1 and P30 genes

PBL and AF DNA were extracted by the salting out method using the Sodium Chlorure $6 \mathrm{M}$ and precipitated with ethanol ${ }^{16}$. The DNA pellet was dissolved in TE buffer and concentrations were then determined.
PCR amplification was carried out in two separate assays : nested PCR, using the 35 -fold repetitive DNA region B1 of T. gondii primers sets and conventional PCR-ELISA using the major surface antigen P30 gene primers sets. The primer sequences and the expected size of B1 and P30 genes PCR products are shown in Table 1.

Table 1: B1 and P30 Genes primer sequences for the amplification of T.gondii DNA.

\begin{tabular}{|c|c|c|c|c|}
\hline $\begin{array}{l}\text { Target } \\
\text { Gene }\end{array}$ & Primers & Sequence $\left(5^{\prime} \rightarrow 3^{\prime}\right)$ & Positions & $\begin{array}{l}\text { Size } \\
\text { (bp) }\end{array}$ \\
\hline $\begin{array}{c}\text { B1 } \\
\text { (Nested } \\
\text { PCR) }\end{array}$ & $\begin{array}{l}\text { Outer sense strand } \\
\text { Outer nonsense strand } \\
\\
\text { Inner sense strand } \\
\text { Inner nonsense strand }\end{array}$ & $\begin{array}{l}\text { Tx2 : TCT TTA AAG CGT TCG TGG TC } \\
\text { Tx4 : GGA ACT GCA TCC GTT CAT GAG } \\
\text { Tx1 : GGC GAC CAA TCT GCG AAT ACA ACC } \\
\text { Tx3 : TGC ATA GGT TGC AGT CAC TG }\end{array}$ & $\begin{array}{l}887-868 \\
694-714 \\
853-831 \\
757-776\end{array}$ & 193 \\
\hline $\begin{array}{c}\text { P30 } \\
\text { (PCR- } \\
\text { ELISA) }\end{array}$ & $\begin{array}{l}\text { Sense strand } \\
\text { Nonsense strand }\end{array}$ & $\begin{array}{l}\text { GBI5 : AGC TGG TGG ACG GGG GAT TC } \\
\text { GBI6 : GTC TGC ACC GTA GGA GCA CC) }\end{array}$ & $\begin{array}{l}689-709 \\
875-895\end{array}$ & 126 \\
\hline
\end{tabular}

For nested PCR using the B1 gene, previously described by Burg ${ }^{17}$, amplification was carried out in a $50 \mu \mathrm{l}$ reaction mixture containing $10 \mathrm{mM}$ Tris- $\mathrm{HCl}(\mathrm{pH} 9.0), 50$ $\mathrm{mM} \mathrm{KCl}, 1.5 \mathrm{mM} \mathrm{MgCl}_{2}$ (Promega, France), $0.2 \mathrm{mM}$ of each dNTP (Bohringer Mennheim, Germany), 50 pmol of each primer (Diasorin, Biomedica, Italy), $2.5 \mathrm{U}$ of Taq DNA polymerase (Promega, France)and DNA extracted from each sample. Reactions were run in a Perkin-Elmer thermocycler by using a step cycle program. After initial denaturation of the DNA at $94^{\circ} \mathrm{C}$ for 5 min, 40 cycles were run: $60 \mathrm{~s}$ with a denaturing temperature of $94^{\circ} \mathrm{C}, 60$ $\mathrm{s}$ with an annealing temperature of $55^{\circ} \mathrm{C}$, and $90 \mathrm{~s}$ with an extension temperature of $72^{\circ} \mathrm{C}$, with a $5 \mathrm{~min} 72^{\circ} \mathrm{C}$ extension after the 40 cycles. After the first 40 cycles, $10 \mu \mathrm{l}$ of each sample was transferred to a second PCR reaction into $40 \mu \mathrm{l}$ of fresh mixture containing the inner primers pair and the procedure was repeated for 35 cycles.

The conventional PCR-ELISA was assessed for the amplification of the P30 gene ${ }^{18}$ using specific primers and under the same conditions as B1 gene for 40 cycles.

Each amplification run included negative and positive controls. All samples were tested in duplicate. Amplicons were revealed by ethidium bromide on $2 \%$ agarose gel electrophoresis, and then visualized under UV illumination.

For P30 gene, detection of hybrids was performed by an ELISA-PCR kit (GEN-ETI-K, DEIA, Diasorin, Italy) as described by the manufacturer. The solid phase was prepared in advance : the wells of a microplate were coated with biotinylated DNA probe (5' TCCCTT GATGCAACCGACCACAAA). A result was considered positive when one reaction yielded an amplification product hybridizing to the specific DNA probe.

\section{Results:}

\section{Antibody detection}

According to respective levels of anti-Toxoplasma IgG and IgM in the first positive sample and in the second one, a Toxoplasma seropositive status during pregnancy was defined in $57(39.8 \%)$ women. Table 2 shows the huge diversity of the techniques used and presents data on the levels of antibody detection. 
Table 2: Serological (ELISA) and molecular (PCR) results from 57 Toxoplasma seropositifs pregnant women

\begin{tabular}{|c|c|c|c|c|c|c|c|c|c|c|}
\hline \multirow{3}{*}{$\begin{array}{l}\text { Patient } \\
\mathrm{N}^{\circ}\end{array}$} & \multirow{3}{*}{$\begin{array}{l}\text { Gestational } \\
\text { Age (weeks) }\end{array}$} & \multirow{2}{*}{\multicolumn{5}{|c|}{ Anti-Toxoplasma antibodies }} & \multicolumn{4}{|c|}{$\begin{array}{l}\text { DNA amplification } \\
\text { (duplicate assays results) }\end{array}$} \\
\hline & & & & & & & \multicolumn{2}{|c|}{$\begin{array}{l}\text { PCR-ELISA } \\
\text { (P30 gene) }\end{array}$} & \multicolumn{2}{|c|}{$\begin{array}{l}\text { Nested PCR } \\
\text { (B1 gene) }\end{array}$} \\
\hline & & IgA & IgM & $\begin{array}{l}\text { IgG } \\
\text { (IU) }\end{array}$ & $\begin{array}{l}\text { IgG } \\
\text { Avidity (\%) }\end{array}$ & Diagnosis & Blood & $\mathbf{A F}$ & Blood & $\mathbf{A F}$ \\
\hline 1 & 16 & + & + & 220 & 18 & $\mathbf{A I}$ & $+/-$ & $-/-$ & $+/+$ & $-/-$ \\
\hline 2 & 16 & - & + & $>240$ & 63 & CI & $-/-$ & & $-/-$ & \\
\hline 3 & 20 & - & - & $>240$ & 67 & CI & $-/-$ & & $-/-$ & \\
\hline 4 & 16 & + & + & $>240$ & 15 & AI & $+/+$ & $-1-$ & $+/+$ & $-1-$ \\
\hline 5 & 15 & - & + & $>240$ & 71 & $\begin{array}{l}\text { CI } \\
\end{array}$ & $-1-$ & $-/-$ & $-/-$ & $-/-$ \\
\hline 6 & 16 & - & + & $>240$ & 65 & CI & $-/-$ & & $-/-$ & \\
\hline 7 & 8 & - & + & $>240$ & 20 & AI & $+/+$ & & $+/+$ & \\
\hline 8 & 19 & - & + & $>240$ & 58 & CI & $-/-$ & & $-/-$ & \\
\hline 9 & 12 & - & - & $>240$ & 47 & CI & $-/-$ & & $-/-$ & \\
\hline 10 & 12 & - & - & $>240$ & 62 & $\mathbf{C I}$ & $-/-$ & & $-/-$ & \\
\hline 11 & 16 & - & + & $>240$ & 55 & $\mathbf{C I}$ & $-/-$ & & $-/-$ & \\
\hline 12 & 13 & - & - & $>240$ & 49 & CI & $-/-$ & & $-1-$ & \\
\hline 13 & 16 & - & + & 114 & 44 & CI & $-/-$ & $-1-$ & $-/-$ & $-/-$ \\
\hline 14 & 14 & - & + & $>240$ & 28 & IA & $-/-$ & $-/-$ & $-/-$ & $-/-$ \\
\hline 15 & 15 & + & + & $>240$ & 21 & $\mathbf{A I}$ & $+/+$ & $+/+$ & $+/+$ & $+/+$ \\
\hline 16 & 8 & - & + & 129 & 70 & CI & $-/-$ & & & \\
\hline 17 & 16 & - & - & 80 & 59 & $\mathbf{C I}$ & $-/-$ & & $-/-$ & \\
\hline 18 & 6 & - & - & $>240$ & 65 & CI & $-/-$ & & $-/-$ & \\
\hline 19 & 16 & - & - & 110 & 51 & CI & $-/-$ & & $-/-$ & \\
\hline 20 & 16 & - & - & $>240$ & 53 & CI & $-/-$ & & $-1-$ & \\
\hline 21 & 12 & - & + & $>240$ & 48 & CI & $-/-$ & & $-/-$ & \\
\hline 22 & 8 & - & + & 125 & 47 & CI & $-/-$ & & $-/-$ & \\
\hline 23 & 13 & - & - & 110 & 52 & CI & $-/-$ & & $-/-$ & \\
\hline 24 & 15 & - & + & 180 & 31 & IA & $-/-$ & $-/-$ & $-/-$ & $-/-$ \\
\hline 25 & 16 & - & + & 240 & 68 & CI & $-/-$ & $-/-$ & $-/-$ & $-/-$ \\
\hline 26 & 14 & - & - & 80 & 60 & CI & $-/-$ & & $-/-$ & \\
\hline 27 & 10 & + & + & 240 & 14 & AI & $+/+$ & & $+/+$ & \\
\hline 28 & 8 & - & - & 112 & 52 & CI & $-/-$ & & $-/-$ & \\
\hline 29 & 15 & + & + & $>240$ & 16 & AI & $+/+$ & $+/+$ & $+/+$ & $+/+$ \\
\hline 30 & 16 & - & - & $>240$ & 42 & CI & $-1-$ & & $-/-$ & \\
\hline 31 & 12 & - & - & 180 & 47 & CI & $-/-$ & & $-/-$ & \\
\hline 32 & 14 & - & - & 220 & 51 & CI & $-/-$ & & $-/-$ & \\
\hline 33 & 14 & - & + & $>240$ & 68 & CI & $-/-$ & & $-/-$ & \\
\hline 34 & 16 & + & + & $>240$ & 20 & AI & $+/+$ & $+/-$ & $+/+$ & $+/+$ \\
\hline 35 & 13 & - & - & $>240$ & 43 & CI & $-/-$ & & $-/-$ & \\
\hline 36 & 15 & - & + & $>240$ & 44 & CI & $-/-$ & $-/-$ & $-/-$ & $-/-$ \\
\hline 37 & 11 & - & - & 220 & 71 & CI & $-/-$ & & $-/-$ & \\
\hline 38 & 13 & - & - & 240 & 65 & CI & $-/-$ & & $-/-$ & \\
\hline 39 & 18 & - & - & $>240$ & 49 & CI & $-/-$ & & $-/-$ & \\
\hline 40 & 12 & - & - & 118 & 46 & CI & $-/-$ & & $-/-$ & \\
\hline 41 & 16 & - & - & 200 & 29 & IA & $-/-$ & $-/-$ & $-/-$ & $-1-$ \\
\hline 42 & 12 & - & + & 180 & 39 & CI & $-/-$ & & $-/-$ & \\
\hline 43 & 15 & - & + & $>240$ & 19 & AI & $+/+$ & $-1-$ & $+/+$ & $-/-$ \\
\hline 44 & 10 & - & - & $>240$ & 61 & CI & $-/-$ & & & \\
\hline 45 & 14 & - & - & $>240$ & 42 & CI & $-/-$ & & $-1-$ & \\
\hline 46 & 11 & - & - & 140 & 43 & CI & $-/-$ & & $-/-$ & \\
\hline 47 & 8 & - & - & 220 & 52 & CI & $-/-$ & & $-/-$ & \\
\hline 48 & 10 & - & + & 240 & 41 & CI & $-/-$ & & $-/-$ & \\
\hline 49 & 9 & - & - & $>240$ & 42 & CI & $-/-$ & & $-1-$ & \\
\hline 50 & 11 & - & - & $>240$ & 52 & CI & $-/-$ & & $-1-$ & \\
\hline 51 & 12 & - & + & 220 & 46 & CI & $-/-$ & & $-/-$ & \\
\hline 52 & 12 & - & - & $>240$ & 44 & CI & $-/-$ & & $-/-$ & \\
\hline 53 & 15 & - & - & 240 & 46 & CI & $-/-$ & & $-/-$ & \\
\hline 54 & 16 & + & + & 114 & 20 & AI & $+/+$ & $+/+$ & $+/+$ & $+/+$ \\
\hline 55 & 17 & - & - & $>240$ & 55 & CI & $-1-$ & & $-/-$ & \\
\hline 56 & 10 & - & + & 240 & 51 & CI & $-/-$ & & $-/-$ & \\
\hline 57 & 9 & - & - & $>240$ & 50 & $\begin{array}{l}\text { CI } \\
\end{array}$ & $-/-$ & & $-/-$ & \\
\hline
\end{tabular}

AI: Acute Infection, CI: Chronic Infection, IA: Intermediate Avidity, AF: Amniotic Fluid, IU: International Unit

Duplicate assays results are given for DNA amplification.

The IgG ELISA antibodies were evaluated with the following IU:between 80 and 220 in 20 women (35\%) and 240 in 37 women (64.9\%). For IgM antibodies, 27 (47.3\%) of 57 cases tested positive with high titers. The IgA antibodies were found in 7 out of $57(12.2 \%)$ samples (Tab. 3). 
Table 3: Rates of Toxoplasma acute infection among the study pregnant women. Diagnosis was performed on blood and amniotic fluid samples.

\begin{tabular}{|c|c|c|c|c|c|c|c|c|c|c|c|c|c|}
\hline \multirow{4}{*}{ Trimester } & \multirow{2}{*}{\multicolumn{6}{|c|}{ Serological Results }} & \multicolumn{6}{|c|}{ PCR Results } & \multirow[b]{3}{*}{ Diagnosis (AI) } \\
\hline & & & & & & & \multicolumn{3}{|c|}{ B1 gene } & \multicolumn{3}{|c|}{ P30 gene } & \\
\hline & \multicolumn{2}{|c|}{$\operatorname{Ig} A$} & \multicolumn{2}{|c|}{ IgM } & \multicolumn{2}{|c|}{ Low Avidity } & \multicolumn{2}{|c|}{ Blood } & $\mathbf{A F}$ & \multicolumn{2}{|c|}{ Blood } & $\mathbf{A F}$ & \\
\hline & Nbr & $(\%)$ & Nbr & $(\%)$ & Nbr & $(\%)$ & Nbr & $(\%)$ & Nbr & Nbr & $(\%)$ & Nbr & Nbr \\
\hline First & $1 / 57$ & (1.75) & $12 / 57$ & (21.05) & $4 / 57$ & $(7.01)$ & $1 / 57$ & (1.75) & $0 / 14 \quad(0.00)$ & $1 / 57$ & (1.75) & $0 / 14 \quad(0.00)$ & $(\mathbf{1 . 7 5 )}$ \\
\hline Second & $7 / 57$ & (12.28) & $15 / 57$ & (26.31) & $\mathbf{5} / \mathbf{5 7}$ & $(8.77)$ & $8 / 57$ & (14.03) & $4 / 14 \quad(28.57)$ & $8 / 57$ & (14.03) & $4 / 14 \quad(28.57)$ & $(14.03)$ \\
\hline
\end{tabular}

AF : Amniotic Fluid

AI : Acute Infection

Among the 57 women, a total of $30(52,6 \%)$ sera were IgG+/IgM-, while $27(47.3 \%)$ sera were $\mathrm{IgG}+/ \mathrm{IgM}+$. No sera sample was $\mathrm{IgG}-/ \mathrm{IgM}+$.

A possible acute infection was suspected for 14 women on the basis of a combination of positive specific IgG/ $\operatorname{IgM}$ and/or IgA, using two blood samples from each patient, with respectively an interval of 21 days.

\section{IgG Avidity}

Toxoplasma IgG Avidity assay has been performed on 57 sera with IgG positive results. High avidity antibodies (indicative of chronic toxoplasmosis) were present in 45 $(78.9 \%)$ women ; intermediate avidity was determined for $3(5.2 \%)$ women and low IgG avidity antibodies (indicative of acute toxoplasmosis) were found in $9(15.7 \%)$ women, without evidence of Toxoplasma infection (Tab. 2). Therefore, 9 out 14 suspected infected women showed low IgG avidity which confirmed an acute infection.

Women, with positive IgM and IgA, were shown to be recently infected indicating an active toxoplasmosis infection (Tab. 2). All subjects presenting an acute toxoplasmosis were at least in the first (1 women out 9$)$ or second ( 8 women out 9 ) trimesters of their pregnancies. Therefore, toxoplasmosis infection occurred most likely before or just after conception with a substantial risk for the fetus.

\section{Polymerase chain reaction assay}

The PCR results are summarized in Table 2. T.gondii DNA was detected by PCR targeting of the B1 and P30 genes in 9 of $57(15.7 \%)$ blood samples and 4 of $14(28.5 \%) \mathrm{AF}$ samples obtained from pregnant women. PCR positive results with the AF samples demonstrated a congenital toxoplasmosis. A total of 8 women out 9 were in the second trimester of their pregnancies (Tab. 3).

All the PCR positive cases were seropositive ; these included 7 samples $(12.2 \%)$ that were positive for $\operatorname{IgG}, \operatorname{IgM}$ and IgA antibodies and $2(3.5 \%)$ samples that were positive for both IgM and IgG antibodies. A high IgG avidity and a negative PCR results excluded recent Toxoplas$m a$ infection in the other women. With regard to positif PCR and low IgG avidity results, 7/9 patients have an IgG-ELISA value $\geq 240 \mathrm{IU}$ and a positive IgA antibodies. Viewed separately, IgG avidity alone didn't demonstrate the acute or chronic infectious status in 3 women who showed an intermediate IgG avidity, whereas PCR gave negative signals with both gene targets and demonstrate a chronic infectious status for these women.

The PCR-ELISA targeting the P30 gene had a lowest sensitivity compared to the nested PCR targeting the B1 gene. In fact, when PBL and AF samples were used, only one assay out of two duplicate tests returned positive (patients 1 for PBL samples and patients 15 and 34 for AF). No PCR product was obtained with the negative controls in any experiment.

\section{Discussion:}

When a $T$. gondii primary infection is acquired during pregnancy, the parasite may be transmitted to the fetus. The parasite reaches the fetus transplacentally, causing various degrees of damages, depending on: the virulence of the parasite, the immune response of the mother and at what trimester the infection was acquired, resulting in fetal death or in severe clinical symptoms ${ }^{6}$. Pregnant 
women are frequently asymptomatic, making a diagnosis difficult. Determination of recently acquired $T$. gondii infection in pregnant women must be made as early as possible to begin an adequate anti-parasitary treatment wich can improve the prognosis ${ }^{19}$.

Currently, the diagnosis of toxoplasmosis is based on immunological testing that give the titer of circulating antibodies. The presence of specific, $\operatorname{IgM}^{20}$ or $\operatorname{IgA},,^{21,22}$ may help to identify recent infection. However, increased levels of IgG and IgM antibodies do not distinguish a recent infection from one acquired a long time before. Therefor, a rapid and effective diagnosis is crucial to initiate an adequate treatment.

In the present study, the tests we used for clarifying the serological status of pregnant women showed IgG and/ or IgM anti-Toxoplasma antibodies for 57 (39.8\%) out 143 women, which represent the global prevalence of anti- $T$ gondii $\mathrm{IgG}$ antibodies in this population. Toxoplasma infection during pregnancy was suspected among 14 women according to respective level of anti-Toxoplasma IgG and $\operatorname{IgM}$ in the first and second samples. On the other hand, results revealed higher IgA antibody titers from acutely infected pregnant women which indicates that in the presence of Toxoplasma specific IgG and IgM antibodies, the additional presence of $\operatorname{IgA}$ was sufficient to identify the acquisition of infection within the previous 8 to 16 weeks. There is an association between the high level of IgA and IgM which may indicate acute phase of toxoplasmosis. It has faster kinetics, suggesting that the infection occurred less than eight months previously ${ }^{23,24}$. IgA antibody determination seems to be important for screening of pregnant women and for prenatal diagnosis.

When using the presence of specific IgM as criteria for identifying $T$. gondii infection in early pregnancy, many women will be falsely identified as possibly infected and unnecessarily undergo diagnostic amniocentesis and antiparasitic treatment. In fact, true positive results must be carefully interpreted ${ }^{25}$ as IgM antibodies might persist for years after primary infection (residual $\operatorname{IgM})^{11,26}$. This fact has limited the use of these methods, because it is not possible to determine if the patient has an acute infection or if the infection had occurred months before ${ }^{27}$. Serological testing may fail during the active phase of T. gondii infection because the antibodies titres are low; therefore, the high risk of congenital toxoplasmosis of a fetus may be undetected because the pregnant mother might test negative during the active phase of $T$. gondii infection. The ideal situation for the diagnosis of Toxoplasma infection in pregnancy would be to have an antibody-negative sera sample collected before conception or at the beginning of pregnancy. However, this was not possible in this study.

In combination with the serological conventional tests, IgG avidity is an auxiliary test which permits to differentiate past and present Toxoplasma infection when the IgM serological reaction is positive in an asymptomatic patient ${ }^{28,29,30}$. In 1989, Hedman et al. ${ }^{28}$ introduced the IgG avidity methode for detecting recently acquired Toxoplasma infection, based on the strength of the binding of specific IgG to multivalent Toxoplasma antigen ${ }^{31}$ and than on the elution of low avidity antibodies by a protein-denaturing agent, mostly urea ${ }^{32,33}$. During the course of the immune response, there is maturation of antibody affinity that increases progressively over weeks or months. Increase in IgG affinity result from an antigen-driven B-cell selection process, resulting in an increase in complementarity of the antigene-antibody-binding site ${ }^{34}$. This binding strength was found to be low in acute phase and high in chronic phase of toxoplasmosis ${ }^{35,36}$; therefore, detection of a low $\mathrm{IgG}$ avidity is a reliable indicator for recent toxoplasmosis, whereas a high avidity shows that the infection occurred in the previous $4-5$ months ${ }^{37,38}$. This is most useful in pregnant women in their first months of gestation who have a positive test for both $\operatorname{IgG}$ and $\operatorname{IgM}$ Toxoplasma antibodies ${ }^{34}$. In this study, recent infection in 9 pregnant women was confirmed by the low avidity index found by IgG avidity ELISA. In fact, we showed that a low avidity index associated with $\operatorname{IgG}, \operatorname{IgM}$ and/or IgA seroreactivity, is a good indicator that an acute T. gondii infection within the last 4 months has been occured. Among 57 seropositive women, the measure of avidity on the first sera sample have allowed us to take accurate conclusions in $94.7 \%$ of cases. The antibody assay combinations and comparison between conventional ELISA and $\operatorname{IgG}$ avidity have proven to be very useful. Lecolier and Pucheu, ${ }^{39}$ concluded that the Toxoplasma-specific IgG avidity test should be performed with the first blood sample collected in early pregnancy to exclude acute infection during gestation.

For three patients the avidity index showed a border line result. When avidity is low or borderline it may be misleading and a more careful interpretation is critical. 
Low-avidity results may persist for as long as 1 year and should not be considered as a sufficient argument to confirm a recent seroconversion and even less to prescribe invasive procedures like amniocentesis ${ }^{34}$. In these cases direct detection of the parasite is necessary for a definitive diagnosis.

The use of the PCR test enable the rapid detection of specific Toxoplasma genes and its combination with serological tests carried out on PBL and AF, facilitate earlier diagnosis of congenital toxoplasmosis. Among the many factors influencing the PCR outcome, the choice of the DNA target and primers is generally considered as essential. Few DNA target loci have been described for Toxoplasma PCR, but different primer pairs have been used in different assays. The principal gene target remains the 35 -fold repetitive and conserved $\mathrm{B} 1$ gene. The detection level of PCR is 1 to 10 parasites in the presence of $10^{5}$ human leucocytes ${ }^{17}$. In our study, $T$. gondii DNA could be detected in 9 women who showed positive $\mathrm{IgG}$ and IgM antibodies as well as low IgG avidity suggesting that these women may have acquired infection during pregnanacy. With regards to the PCR assay by the use of PBL and AF, both B1 and P30 primer sets performed quite equally well and therefore appear adequate for Toxoplasma identification; but, with primer set P30, an additional step (achieved through an ELISA-PCR assay) for confirming the identity of the PCR product is of utter importance. However, B1 gene proved valuable PCR for T. gondii detection better than P30 gene. Our results showing 3 false negative PCR (Tab. 2), are in agreement with those of Bastien $^{40}$ who validate the current choice targeting B1 gene, which appear clearly more sensitive than assays targeting the single copy P30 gene.

The PCR results were in concordance with those of $\mathrm{IgG}$ avidity test. Moreover, PCR was very helpful in cases of intermediat avidity. 3 cases were $\operatorname{IgG}$ avidity borderline but PCR negative.

Based on the results of this study, the $\operatorname{IgG}$ avidity and the PCR tests performed better than the conventional ELISA for the diagnosis of Toxoplasma infection in pregnant women.

When only conventional ELISA was used, 24.5\% (14 of 57) acute infections were suspected. When ELISA and IgG avidity were combined, 3 suspected infections out of $14(05.2 \%)$ yielded an intermediat avidity. When ELISA,
IgG avidity, and PCR findings were combined, the acute toxoplasmosis of pregnant women could be demonstrated in $15.7 \%$ of cases ( 9 of 57 ). This study confirms the complementary need of the techniques used for the screening of pregnant women, but some authors recommend PCR than most serologic techniques ${ }^{13}$

\section{Conclusion:}

In this study, the conventional serodiagnosis of toxoplasmosis, on the basis of the first and the second sera sample, was sufficient to determine the serological status of most women and the demonstration of $\operatorname{IgA}$ antibody appears useful for diagnosis of Toxoplasma infection. However, this is was not possible for some women. The IgG avidity assay has been demonstrated to have the utility to exclude recent infection in early pregnancy for women who otherwise, on the basis of a positive specific IgM result, would have been identified as having a recent infection. From these results it can be concluded that $\operatorname{IgG}$ avidity, performed in single samples from positive anti-Toxoplasma IgM pregnant women, is a valuable diagnostic tool. Overmore, single PCR-negative samples in conjunction with an IgG/IgM positive test result could confirm a past infection in the presence of serologic results that are difficult to interprete, especially for intermediate avidity.

The main finding of our study was the significant association between high IgG anti-T. gondii titers, low index avidity and PCR detection of T. gondii DNA and the diagnosis of acute toxoplasmosis. Moreover, the molecular biology technique was useful in pregnant women with seroconversion, to exclude the presence of $T$. gondii $\mathrm{DNA}$ in $\mathrm{AF}$. These women will be saved from unnecessary anxiety, additional examinations and treatment. However, to the best of our knowledge, no studies have been published using both IgG avidity and PCR for the diagnosis of toxoplasmosis on pregnant women in Algeria. We hope that our study will open new perspectives for the systematic introduction of these techniques in the diagnosis of toxoplasmosis.

\section{Conflict of interest:}

The authors declare that they have no conflicts of interest.

\section{References:}

1. Petersen E, Dubey JP. Biology of Toxoplasma gondii. In: Joynson DH, Wreghitt T, editors. Toxoplasmosis: 
a Comprehensive Clinical Guide. Cambridge University Press; 2001 pp 1-49.

2. Remington JS, McLeod R, Wilson CB, Desmonts G. Toxoplasmosis. In: Remington JS, Klein JO, editors. Infectious diseases of the fetus and newborn infant. 7 th ed. Pennsylvania Elsevier, 2011 pp 918-1041.

3. Luft BJ, Remington JS. Toxoplasmic encephalitis in AIDS. Clinical Infectious Diseases 1992;15(2):211-222.

http://www.ncbi.nlm.nih.gov/pubmed/1520757

4. Edward CG. Toxoplasmosis. Medicine. 2014;42(1):31-33.http: / / a c.els-cdn.com / S1357303913002922/1-s2.0-S1357303913002922-main. pdf?_tid=a59e5c7a-032d-11e5-adea-00000aab0f27\&acdnat $=1432593209 \_8219 c 53 a c 4 c 7 c a 89266 f 6 a 9 a 66 c 458 \mathrm{e} 2$

5. Wrong S, Remington JS. Toxoplasmosis in pregnancy. Clinical Infectious Diseases 1994;18(6):853-861.

http://www.ncbi.nlm.nih.gov/pubmed/8086543

6. Dunn, D, Wallon M, Peyron F, Petersen E, Peckham C, Gilbert R. Mother-to-child transmission of toxoplasmosis: risk estimates for clinical counselling. Lancet. 1999;353:1829-1833.

http://www.ncbi.nlm.nih.gov/pubmed/10359407

7. Moncada PA, Montoya JG. Toxoplasmosis in the fetus and newborn: an update on prevalence, diagnosis and treatment. Expert Review of Anti-Infective Therapy 2012;10:815-828.

http://informahealthcare.com/doi/abs/10.1586/ eri.12.58

8. Stray-Pedersen B. Treatment of toxoplasmosis in the pregnant mother and newborn child. Scandinavian Journal of Infecioust Disease Supplement 1992;84:23-31.

http://www.ncbi.nlm.nih.gov/pubmed/1290070

9. James GS, Sintchenko VG, Dickeson DJ, Gilbert GL. Comparison of cell culture, mouse inoculation, and PCR for detection of Toxoplasma gondii: effects of storage conditions on sensitivity. Journal of Clinical Microbiology 1996;34(6):1572-1575.

http://www.ncbi.nlm.nih.gov/pmc/articles / PMC229067/

10. Liesenfeld O, Montoya JG, Kinney S, Press C, Remington JS. Effect of testing for IgG Avidity in the diagnosis of Toxoplasma gondii infection in pregnant women: Experience in a US Reference Laboratory. Journal of Infectious Diseases 2001;183(8):1248-1253.

http://jid.oxfordjournals.org/content/183/8/1248.full. pdf
11. Lappalainen M, Koskela P, Koskiniemi M, et al. Toxoplasmosis aquired during pregnancy: improved serodiagnosis based on avidity of IgG. Journal of Infectious Diseases 1993;167(3):691-697.

http://www.ncbi.nlm.nih.gov/pubmed/8440939

12. Delhaes L, Yera H, Ache S, Tsatsaris V, Houfflin-Debarge V. Contribution of molecular diagnosis to congenital toxoplasmosis. Diagnostic Microbiology and Infectious Disease 2013;76:244-247.

h t t p : / / w w w. n c bi.nlm.nih.gov/pubmed/23518182?dopt=Abstract

13. Kaiser K, Van Loon AM, Pelloux H, Ferrandiz J, Picot S, Wallace P, Peyron F. Multicenter proficiency study for detection of Toxoplasma gondii in amniotic fluid by nucleic acid amplification methods. Clin Chim Acta 2007;375(12):99-103.

h t t p : / / w w w. n c bi.nlm.nih.gov/pubmed/16860303?dopt=Abstract

14. Jenum P, Stray-Pedersen B, Gundersen AG. Improved diagnosis of primary Toxoplasma gondii infection in early pregnancy by determination of antitoxoplasma immunoglobulin G Avidity. Journal of Clinical Microbiology 1997;35(8):1972-1977.

http://www.ncbi.nlm.nih.gov/pubmed/9230365

15. Villard O, Breit L, Cimon B, et al. The French National Reference Center for Toxoplasmosis Network. Comparison of four commercially available avidity tests for Toxoplasma gondii-specific IgG antibodies. Clinical Vaccine immunology 2013;20(2):197-204.

http://www.ncbi.nlm.nih.gov/pubmed/23239801

16. Miller SA, Dykes DD, Polesky HF. A simple salting out procedure for extraction DNA from human nucleated cells. Nucleic Acide Research 1988;16(3):1215-1217.

http: / / www.ncbi.nlm.nih.gov/pmc/articles / PMC334765/

17. Burg JL, Grover CM, Pouletty P, Boothroyd JC. Direct and sensitive detection of a pathogenic protozoan, Toxoplasma gondii by polymerase chain reaction. Journal of Clinical Microbiology 1989;27(8):1787-1792.

http://www.ncbi.nlm.nih.gov/pubmed/2768467

18. Moleon I, Beuchamp P, Cesbron MF, Tourvieille B. Cloning of the gene encoding the p30 antigen of Toxoplasma gondii by PCR to insert it in transgenicmice. Archive of Medical Research 1994;25(4):463-466.

http://www.ncbi.nlm.nih.gov/pubmed/7858408 19. Hohlfeld P, Daffos F, Thulliez P, et al. Fetal toxoplas- 
mosis: outcome of pregnancy and infant follow-up after in utero treatment. Journal of Pediatry 1989;115(5):765-769. http://www.ncbi.nlm.nih.gov/pubmed/2681638

20. Desmonts G, Naot Y, Remington JS. Immunoglobulin $\mathrm{M}$ immunosorbent agglutination assay for diagnosis of infectious diseases: diagnosis of acute congenital and acquired Toxoplasma infections. Journal of Clinical Microbiology 1981;14(5):486-491.

http://www.ncbi.nlm.nih.gov/pubmed/7031082

21. Pinon JM, Thoannes H, Pouletty PH, Poirriez J, Damiens J, Pelletier P. Detection of IgA specific for toxoplasmosis in serum and cerebrospinal fluid using a non-enzymatic IgA-capture assay. Diagnostic Immunology 1986 (5);4:223-227.

http://www.ncbi.nlm.nih.gov/pubmed/3791840

22. Decoster A, Darcy F, Caron A, Capron A. IgA antibodies against $\mathrm{P} 30$ as markers of congenital and acute toxoplasmosis. Lancet 1988;ii:1104-1107.

http://www.ncbi.nlm.nih.gov/pubmed/2903324

23. Rodrigues IM, Castro AM, Gomes MB, Amaral WN, Avelino MM. Congenital toxoplasmosis: evaluation of serological methods for the detection of anti-Toxoplasma gondii IgM and IgA antibodies. Memorias do Instituto Oswaldo Cruz 2009;104:434-440

http://www.scielo.br/scielo.php?pid=S0074-027620090 $00300006 \&$ script $=$ sci_arttext\&tlng $=$ pt

24. Francis JM, Joynson DH. Duration of specific immunoglobulin A antibody following acute toxoplasmosis as determined by enzyme immunoassay and immunosorbent agglutination assay. European Journal of Clinical and Microbiological Infectious Diseases 1993;12(7):556-559.

h t t p : / / w w w. n c bi.nlm.ni h.gov/ p u bmed/8404920?dopt=Citation

25. Liesenfeld O, Press C, Montoya J, et al. False-positive results in immunoglobulin IgM) Toxoplasma antibody tests and importance of confirmatory testing: Platelia Toxo- IgM test. Journal of Clinical Microbiology 1997;35(1):174-718.

h t t p : / / ww w. n c bi.nlm.nih.gov/ pubmed/8968902?dopt=Citation

26. Wong SY, Hadju MP, Ramirez R, Thulliez P, McLeod $\mathrm{R}$, Remington JS. Role of specific immunoglobulin $\mathrm{E}$ in diagnosis of acute Toxoplasma infection and toxoplasmosis. Journal of Clinical Microbiology 1993;31(11):2952-2959.

http:/ / www.ncbi.nlm.nih.gov/pmc/articles / PMC266169/

27. Wilson M, Remington JS, Clavet C, Varney G, Press
C. Evaluation of six commercial kits for the detection of immunoglobulin $\mathrm{M}$ antibodies to Toxoplasma gondii, the FDA toxoplasmosis Ad Hoc Working Group. Journal of Clinical Microbiology 1997:35(12):3112-3115.

http://www.ncbi.nlm.nih.gov/pubmed/9399504

28. Fricker-Hidalgo H, Saddoux C, Suchel-Jambon AS, Romand S, Foussadier A, Pelloux H, Thulliez P. New Vidas assay for Toxoplasma-specific IgG avidity: evaluation on 603 sera. Diagnostic Microbiology and Infectious Disease 2006;56:167-172.

http://www.ncbi.nlm.nih.gov/pubmed/16725296

29. Lappalainen M, Hedman K. Serodiagnosis of toxoplasmosis. The impact of measurement of IgG avidity. Annals Ist Super Sanita 2004;40(1):81-88.

http://www.ncbi.nlm.nih.gov/pubmed/15269456

30. Pelloux H, Brun E, Vernet G, et al. Determination of anti-Toxoplasma gondii immunoglobulin $G$ avidity: Adaptation to the Vidas system (BioMerieux). Diagnosis of Microbiological Infectious Diseases 1998;32(2):69-73.

http://www.ncbi.nlm.nih.gov/pubmed/9823527

31. Roitt IM. Essential immunology. Blackwell Scientific Publications: Oxford 1988 pp 60-63.

32. Candolfi E, Pastor R, Huber R, Filisetti D, Villard O. IgG avidity assay firms up the diagnosis of acute toxoplasmosis on the first serum sample in immunocompetent pregnant women. Diagnostic and Microbiological Infectious Diseases 2007;58(1):83-88.

http://www.ncbi.nlm.nih.gov/pubmed/17368807

33. Petersen E, Borobio MV, Guy E, et al. European multicenter study of the LIAISON automated diagnostic system for determination of Toxoplasma gondii-specific immunoglobulin $\mathrm{G}$ ( $\mathrm{IgG}$ ) and IgM and the IgG avidity index. Journal of Clinical Microbiology 2005;43(4):1570-1574. http://www.ncbi.nlm.nih.gov/pubmed/15814967

34. Remington JS, Thulliez F, Montoya JG. Recent developements for diagnosis of Toxoplasmosis. Journal of Clinical Microbiology 2004;42(3):941-945.

http://www.ncbi.nlm.nih.gov/pubmed/15004036

35. Iqbal J, Khalid N. Detection of acute Toxoplasma gondii infection in early pregnancy by IgG avidity and PCR analysis. Journal of Medical Mi $\neg$ crobiology 2007;56(11):14951499.

http://www.ncbi.nlm.nih.gov/pubmed/17965351

36. Hedman K, Lappalainen M, Sönderlund M, Hedman L. Avidity of IgG in serodiagnosis of infectious diseases. Revue of Medicinal Microbi $\neg$ ology 1993;4:123-29.

37. Flori P, Bellete B, Crampe C, et al. A technique for 
dating toxoplasmosis in pregnancy and comparison with the Vidas an $\neg$ ti an $\neg$ ti-Toxoplasma IgG avidity test. Clinical Microbiological Infection 2008;14(3):242-249.

http:// onlinelibrary.wiley.com/doi/10.1111/j.14690691.2007.01905.x/full

38. Paul M. Immunoglobulin $G$ avidity in diagnosis of toxoplasmic lymphadenopathy and ocular toxoplasmosis. Clinical Diagnosis of Laboratory Immunology 1999;6(4):514-
518. http://www.ncbi.nlm.nih.gov/pubmed/10391853 39. Candolfi E, Pastor R, Huber R, Filisetti D, Villard O. IgG avidity assay firms up the diagnosis of acute toxoplasmosis on the first serum sample in immunocompetent pregnant women. Diagn Microbiol Infect Dis 2007;58:83-88. http://www.ncbi.nlm.nih.gov/pubmed/17368807

40. Bastien P. Molecular diagnosis of toxoplasmosis. Trans Royal Society of Tropical Medical Hygiene 2002;96(1):205-215. http://www.ncbi.nlm.nih.gov/pubmed/12055840 